\title{
Comparison on Cultivating Modes of Hotel Management Majors in Chinese and Foreign Universities
}

\author{
Zhu Zhengjie \\ Tourism and Cuisine School \\ Harbin University of Commerce \\ Harbin, China \\ 46652953@qq.com
}

\author{
Liu Lin \\ Tourism and Cuisine School \\ Harbin University of Commerce \\ Harbin, China \\ bestlyn@163.com
}

\begin{abstract}
Hotel industry is an important pillar of tourism industry in China. And the development of it needs large quantities of high quality human resources. But there is a large gap of tertiary education in hotel management comparing with foreign universities. This article studies the effective cultivating modes of hotel management majors in foreign universities. Then it makes comparative analysis on cultivating aim, teaching content, practical teaching, teaching level, teaching approach, teaching method and teaching evaluation. At last, it proposes optimization approach on cultivating mode of hotel management major in Chinese universities in using foreign cultivating mode for reference.
\end{abstract}

Keywords-cultivating mode; hotel management; major cultivating; university

\section{INTRODUCTION}

The tertiary education in hotel management develops gradually with the development of hospitality industry in China. But there are still some shortcomings on cultivating mode of hotel management majors. It couldn't cater to the ever-changing market requirements of hospitality industry. Also it lags the development of hospitality industry. So there should be certain adjustments on current cultivating mode of hotel management majors. This article takes two top-ranked colleges from China and foreign countries respectively as examples. Their cultivating molds and graduates are always praised by people. So a detailed comparison of their cultivating modes of hotel management majors will be made. They are Swiss hospitality school in Ecole Hoteliere de Lausanne, School of Hotel Administration in Cornell University from abroad and Tourism College in Beijing Union University and School of Hospitality Management in Beijing International Studies University in China.

\section{COMPARISON ON CULTIVATING MODES OF HOTEL MANAGEMENT MAJORS IN CHINESE AND FOREIGN UNIVERSITIES}

One of the important missions of hotel tertiary education is cultivating high-quality hotel management majors. With the progress of science and information technology, more and

This research was financially supported by teaching reform and research project of Harbin University of Commerce (Grant NO. HSDJY09(Z) ) and education scientific planning project in Heilongjiang Province (Grant NO.GLC1316109). more high international standards are applied to the way of running a university and purchasing teaching equipments in domestic universities. But there is still big difference between Chinese and foreign universities on cultivating aim, teaching system, teaching contents, practical teaching and teaching levels because of the different culture background and education system $^{[1]}$.

TABLE I. COMPARISON ON CULTIVATING Aim OF HOTEL MANAGEMENT MAJOR

\begin{tabular}{|c|c|}
\hline $\begin{array}{c}\text { Name of } \\
\text { School }\end{array}$ & Cultivating Aim \\
\hline $\begin{array}{c}\text { Ecole } \\
\text { Hoteliere de } \\
\text { Lausanne }\end{array}$ & $\begin{array}{c}\text { cultivating senior management for international } \\
\text { hospitality, especially for first-class hotels, restaurants } \\
\text { and chain hotels worldwide }\end{array}$ \\
\hline $\begin{array}{c}\text { Cornell } \\
\text { University }\end{array}$ & $\begin{array}{c}\text { cultivating leaders for 21st century global hospitality } \\
\text { industry }\end{array}$ \\
\hline $\begin{array}{c}\text { Beijing Union } \\
\text { University }\end{array}$ & $\begin{array}{c}\text { cultivating senior application-oriented graduates with } \\
\text { the ability of solving practical problems on hotel } \\
\text { operation and all-round development of morality, } \\
\text { intelligence, physique and aesthetics }\end{array}$ \\
\hline $\begin{array}{c}\text { Beijing } \\
\text { International } \\
\text { Studies } \\
\text { University }\end{array}$ & $\begin{array}{c}\text { cultivating international application-oriented graduates } \\
\text { with development of morality, intelligence physique and } \\
\text { aesthetics, excellent foreign language level, solid } \\
\text { professional basis, reasonable knowledge structure, } \\
\text { innovation spirit, practical ability, adaptability and the } \\
\text { motto of "Integrity, Diligence, Truth and Leadership" }\end{array}$ \\
\hline \multicolumn{2}{|c}{} \\
\hline
\end{tabular}

\section{A. Cultivating Aim}

The difference of cultivating aim is evident between Chinese and foreign universities. Foreign universities set their cultivating aims with high demands and standards. They lay emphasis on cultivating students' ability of studying and working independently, analyzing and solving problem and adapting to the society. The graduates are supposed to be the leader of hospitality industry or senior management in wellknown hotels and restaurants. While Chinese universities just pay attention to teaching basic theoretical knowledge and cultivating senior application-oriented graduates.

\section{B. Teaching Content}

The curriculum in Ecole Hoteliere de Lausanne is taught in six semesters. The main content is about basic skills, hotel management theory and practice, research on current 
problems of hospitality industry. And the fourth semester is for paid-internship program. The core curriculums are the following: Professional Communication Skills, Hotel Information Technology, F\&B Control, Housekeeping Marketing, Housekeeping and Catering Management, Front Desk Theory Practice, Technology Application, Macro Economy, Financial Management, Restaurant Concept Management, Restaurant Design, Restaurant Service Capacity Management, Food Service Information, Food Service Marketing, Housekeeping Management, Micro Economy, Financial Management, Strategy Management, Service Marketing, International Tourism Management, Equipment Management, Hotel Operation Regulations, Hotel Environmental Information Technology, Service Operation Management, Human Resources Management, etc. ${ }^{[2]}$.

The curriculum system in Cornell university is an abilityoriented bachelor system which is designed in accordance with the required capabilities of professional posts. The business curriculum is regarded as the core and divided into three parts: compulsory courses, elective courses and practical courses. There are 22 courses belonging to compulsory course. That is $22 \%$ of the total courses. They are the following: Introduction to the Hotel, Introduction to F\&B Service, Service Operation Management, Restaurant Management, Quantitative Analysis of Service Industry, Organizational Behavior and Relationships, Human Resources Management, Cooking Principle and Practice, Micro Economy of Service industry, Hotel Marketing Management, Strategy Management, Hotel Development and Planning, Hotel Equipment Operation, etc. And elective courses account for $72 \%$ of the total while the rest $7 \%$ is for practical courses ${ }^{[3]}$.

The curriculum in Beijing Union University is oriented towards profession ability and profession quality. The main subjects are economics and business administration. stem There are six major course modules: common courses, specialized basic courses, specialized courses, specialized distributional electives, specialized free electives and practical courses. There are almost 30 courses belonging to core courses, such as Hotel Operation Management, Hotel Recreation Management, F\&B Management, Convention and Exhibition Management, Housekeeping System Management, Hotel Facilities Management, Hotel Environment Management, Hotel Collectivization Operation, Public Relationship, Strategic Management, Introduction to tourism, Tourism Psychology, Economic Law, Statistics, Macro Economy, Tourism Economy, Micro Economy, Management, Human Resources Management, Management Mathematics, Organizational Behavior, etc ${ }^{[4]}$.

The curriculum system in Beijing International Studies University is composed of the following five parts: theoretical common course, economic basic courses, specialized basic course, specialized common course and hotel specialized course. The core courses are the following: Principles of Tourism Law, Principles of Tourism Management, Tourism Economics, Tourism English, Tourism Marketing, Tourism Human Resources Management, Tourism Information Investigation and Retrieval, Principles of Hotel Management, Housekeeping Management, F\&B Management, Front Desk Management, etc ${ }^{[5]}$.

\section{Practical Teaching}

The practical teaching in Ecole Hoteliere de Lausanne is divided into three parts: operational practice lesson, simulative analysis lesson and researchful survey lesson. The students not only make their products personally but also analyze products quality, investigate reasons to the problems and propose solutions. Generally speaking, the students need to have a period of practice after finishing courses of certain category. Then they will have paid-internship program in the hotel for half a year according to the unified arrangement of the school.

School of Hotel Administration in Cornell University arranges the students to practice in campus hotel. The students can either practice in different departments or work from entry-level to second-level in the same department. All students need to have 800-hour experience in a related department of the hotel.

The practical teaching in Beijing Union University is usually combined with analysis and discussion of real cases. And the students need to participate in various activities for completing practical teaching tasks. In the meantime, the content of simulation, emulation, novitiate and internship is added to practical teaching. The students will have specialized internship in summer vacation of the third year or in the seventh semester. The length of the internship is six months. The internship enterprises are usually three-star hotels in the city. The students may arrange their internship by themselves or follow the arrangement of the school.

Hotel management majors in Beijing International Studies University need to complete the prescribed period of practice, practical courses and practice report. The school may arrange the students to practice in star-rated hotels during the summer vacation. And the positions are arranged by school and property in advance. The students have no independent option unless they arrange their internship by themselves.

\section{Teaching Staff}

The teachers in these two foreign universities generally have working experience in the field of hotel management. And the teaching staff consists of two parts, full-time teachers and part-time teachers. The latter is essentially composed of entrepreneurs and experts. Having the experience of hotel operation and management is a must for being teachers in Ecole Hoteliere de Lausanne. The teaching staff of Cornell University includes the following: industry experts with different background, hotel management and restaurant owners, etc. On the other hand, both two universities put emphasis on improving teachers' professional skills. The teaching stuff of Ecole Hoteliere de Lausanne should follow the career mode of hotel-school-hotel-school. Thus the teachers can always grasp forefront information of hospitality industry development and have rich practical experience. For two domestic universities, most of their teachers have received systematic professional training in universities and have doctor's degree in related major. But part-time work in a hotel is not advocated by school. So the teachers lack practical working experience relatively ${ }^{[6]}$. 


\section{E. Teaching Approach and Method}

The difference of teaching approach and method between Chinese and foreign universities is quite evident.

TABLE II. COMPARISON ON TEACHING APPROACH AND METHOD OF HOTEL MANAGEMENT

\begin{tabular}{|c|c|c|}
\hline & Teaching Approach & Teaching Method \\
\hline $\begin{array}{c}\text { Foreign } \\
\text { Universities }\end{array}$ & $\begin{array}{l}\text { Widespread adoption of } \\
\text { modern information } \\
\text { technology approach, such } \\
\text { as: satellite } \\
\text { communications teaching } \\
\text { system, optical fiber } \\
\text { communication teaching } \\
\text { system, modern } 3 \\
\text { dimensional simulation } \\
\text { teaching software, etc. }\end{array}$ & $\begin{array}{l}\text { Follow student-centered } \\
\text { education concept. } \\
\text { Develop students' ability of } \\
\text { independent study through } \\
\text { laboratory operations, case } \\
\text { analysis, investigation, } \\
\text { thinking and discussing, } \\
\text { etc. }\end{array}$ \\
\hline $\begin{array}{c}\text { Chinese } \\
\text { Universities }\end{array}$ & $\begin{array}{l}\text { Traditional teaching } \\
\text { approach is still the } \\
\text { principal one while the } \\
\text { modern one is auxiliary. }\end{array}$ & $\begin{array}{l}\text { Give priority to teaching } \\
\text { by the teachers with the } \\
\text { methods of case analysis, } \\
\text { discussing, experiment, } \\
\text { interactive communication, } \\
\text { etc. }\end{array}$ \\
\hline
\end{tabular}

\section{F. Teaching Evaluation}

The major standard of teaching evaluation in foreign universities depends on the students' improvement. The items of teaching evaluation evaluates not only the teachers' teaching attitude and behavior but also their grasp of curriculum system and knowledge content. Besides, the items of teaching evaluation focus on students' progress through teaching progress and teachers' attention, respect, care and help to the students. The teacher's teaching can be evaluated to be successful only if the students have various rapid progress in the course of learning. Teaching evaluation in domestic universities mainly emphasize the teachers' teaching performance. More items of teaching evaluation are related to students' learning effect without detailed understanding and evaluation of teaching.

\section{DifFERENCE ON CUltivating Modes OF Hotel MANAGEMENT MAJORS IN CHINESE AND FOREIGN UNIVERSITIES}

\section{A. Difference on cultivating concept}

Both two foreign universities give priority to the cultivation of students' practical ability and carry out this kind of cultivation throughout the whole teaching course. They are aiming to cultivate senior management in international hotels. Our domestic universities also pay attention to the cultivation of students' practical ability. But teaching theoretical knowledge is much more important. So the students' practical ability is not strong. Thus domestic universities had better use the experience of foreign universities for reference to strengthen the cultivation of their students' practical ability.

\section{B. Difference on cultivating mode}

The most important feature of cultivating modes in two foreign universities is paying attention to the combination of theory and practice, so is the school-running pattern. This is helpful for cultivating the students' practical ability. So the graduates may meet the demands of the enterprises and the development of hospitality industry. The cultivating modes in our domestic universities also emphasize the combination of theory and practice, but the implementation of industryuniversity-research school-running mode is not enough.

\section{Difference on cultivating orientation}

The cultivating orientation of two foreign universities is career-oriented. And the main content of cultivation is career capacity cultivation. The cultivating orientation of two domestic universities is knowledge-oriented. Mastering the knowledge is the start of teaching and accumulating the knowledge is the final aim. The whole teaching process underlines the importance of knowledge. Although knowledge acquisition and accumulation is the basis of the progress for learners, the cultivation of ability is the most effective recipe. So the cultivation of hotel management majors in our universities should try to be career-oriented by breaking many obstacles.

\section{CONCLUSiOn}

In short, there is certain gap between cultivating modes of hotel management majors in Chinese and foreign universities. So we need to perfect and optimize our cultivating modes. Eventually, we need to find a proper cultivating mode which is suitable for current situation of hotel management major in domestic universities.

\section{REFERENCES}

[1] Yang Huimin, "Foreign institutions of hotel management training model comparison study," Liaoning Normal University, Da Lian: Academic, 2010, pp. 12. (in Chinese)

[2] Xu Honggang and Zhang Zhaozhi, "A Comparative Analysis of Overseas and Chinese Tourism Education and Its Enlightenment," Beijing: Tourism Tribune, 2015, pp.26-33. (in Chinese)

[3] Wang Hong, "Analytical on talent-cultivating pattern of hotel management in institutions of higher in China," Zhengzhou: Journal of Zhengzhou Institute of Aeronautical Industry Management, 2014, pp.8283. (in Chinese)

[4] Fang Xianghong, "Revelation of Interns gap between China and the Unit ed," Beijing: Hotel Modernization, 2015, pp.60-62. (in Chinese)

[5] Zhang Haihong, "'Lausanne mode' and hotel vocational education refor $m$ in our country," Changsha: Journal of Hunan Economic Management College, 2004, pp.104-106. (in Chinese)

[6] Wang Miaomiao, "Undergraduate hotel management education model based on market," Qingdao University, Qingdao: Academic, 2011, pp. 33-44. (in Chinese) 